University of Nebraska - Lincoln

DigitalCommons@University of Nebraska - Lincoln

August 1994

Reply to D. E. Watt, A. S. Alkharam, M. B. Child and M.S. Salikin, "Dose as a Damage Specifier in Radiobiology for Radiation Protection." A Comment on "Dose" (Radiat. Res. 137, 410-413, 1994)

Robert Katz

University of Nebraska-Lincoln, rkatz2@unl.edu

Follow this and additional works at: http://digitalcommons.unl.edu/physicskatz

Part of the Physics Commons

Katz, Robert, "Reply to D. E. Watt, A. S. Alkharam, M. B. Child and M. S. Salikin, "Dose as a Damage Specifier in Radiobiology for Radiation Protection." A Comment on "Dose" (Radiat. Res. 137, 410-413, 1994)" (1994). Robert Katz Publications. 38.

http://digitalcommons.unl.edu/physicskatz/38

This Article is brought to you for free and open access by the Research Papers in Physics and Astronomy at DigitalCommons@University of Nebraska Lincoln. It has been accepted for inclusion in Robert Katz Publications by an authorized administrator of DigitalCommons@University of Nebraska Lincoln. 
Published in Radiation Research, Vol. 139, No. 2 (Aug., 1994), pp. 251-253.

Copyright (C) 1994 Radiation Research Society.

http://www.radres.org/ECOMradres/timssnet/common/tnt frontpage.cfm

Used by permission. 


\section{Reply to D. E. Watt, A. S. Alkharam, M. B. Child and M. S. Salikin, "Dose as a Damage Specifier in Radiobiology for Radiation Protection." A Comment on "Dose" (Radiat. Res. 137, 410-413, 1994)}

\section{Robert Katz}

Department of Physics and Astronomy, University of Nebraska/Lincoln, Lincoln, Nebraska 68588-0111

The authors are generous in observing that "the high degree of success achieved by (Katz's $\delta$-ray theory of track structure) in fits to survival curves for heavy ions, and in analysis and prediction of other biological effects is almost legend." We remind them that the model is physical, and has little to do with biology in an explicit way, except that 
an oversimplified "bean bag" model of a eucaryotic cell is used, in which the bag represents the cell nucleus and the beans represent internal targets. No explicit biologically mechanistic structure or response is inferred. No reference is made to DNA. The model rests on its fit to data rather than on its relationship to a presumed mechanism, however universally that presumption is held.

The model is equally applicable to nuclear emulsions, to enzymes, viruses, bacteria, scintillation counters, to radiation chemistry and, with the above assumption of cellular structure, to eucaryotic cells. Biological parameters appear from fitting the equations of the model with its four parameters to radiobiological data for a variety of end points. We emphasize that in this fitting one set of four parameters must produce fits to all response curves for a single end point obtained with a range of bombarding ions and $\gamma$ rays. It is because of the success of the model in fitting and in extrapolating ${ }^{1}$ data for both homogeneous and heterogeneous radiation fields (for which we know the particle-energy spectra) that we suggest its use in place of the failed concepts of dose, RBE, LET and quality factor. As pointed out in my Commentary on dose (1), we must presently rely on theory to produce knowledge of nuclear fragments, of the particle energy spectrum, and this is clearly a disadvantage. Nor do we know precisely the appropriate set of parameters to use for radiation protection, but a recent survey of radiosensitivity parameters ${ }^{2}$ from over 40 sets of data obtained with HZE particles may help in making this choice.

In this model dose is used to represent the response to $\delta$ rays, $\gamma$ rays and orthovoltage $X$ rays (but not to photons of any energy, and explicitly not to carbon $\mathrm{K} \mathrm{X}$ rays). We recognize that there may be large differences in the energy spectrum from $\delta$ rays at different radial distances from an ion's path, and from $\gamma$ rays. We have ignored this difference in our approximations, and find that the model has not suffered greatly in consequence. We suggest that one test of the validity of a model is its "high degree of success" in achieving its aims. This model is explicitly parametric. It fits data. It is predictive. I suggest that the task of mechanistic modelers is to account for these parameters. I suggest that the most important study is the effect of $\gamma$ rays, for once the parameters for $\gamma$ rays are known, this model can predict the response to heavy ions. It must be astonishing to others as it is to me that a single model is applicable to so many different physical, chemical and biological systems without essential alteration in its concepts. It is difficult to see how it

\footnotetext{
${ }^{1}$ C. X. Zhang and R. Katz, Thindown in radiobiology. Manuscript submitted for journal publication.

${ }^{2}$ R. Katz, R. Zachariah, F. A. Cucinotta and C. X. Zhang, Survey of cellular radiosensitivity parameters. Manuscript submitted for journal publication.
}

could be wrong. It is difficult to see how other concepts whose merit lies in the belief of many investigators that they might be correct, but without demonstrated predictive value, can be considered to be competitive. I understand that belief is highly motivational, that people go to war over belief, that people are said to achieve salvation through belief or through faith, but belief must be far behind predictive value in science.

It is not clear that all survival curves have initial linear slopes (2), or that DNA is the target for cell killing. Hofer $e t$ al. (3) argue that the target is related to DNA, but there may be a larger target structure with which DNA is associated, perhaps in S phase, responsible for cell killing. They also argue that the number of cellular targets doubles in $S$ phase. Thus a cell culture is likely to be heterogeneous, having a survival curve characteristic of the mix of $n$ and $2 n$ target cells in the cell population. Where $n$ is 1 such a mix might well account for the otherwise illogical linear-quadratic fits to survival data after $\gamma$ irradiation. I call these illogical, for I have shown that a linear-quadratic survival curve for $\mathrm{X}$ rays cannot lead to an $\mathrm{RBE}>1$ for heavy-ion bombardment, unless it is essentially indistinguishable from a two-target curve shape (4). It may also account for the observation that sometimes cell cultures exhibiting exponential survival after $\gamma$ irradiation may exhibit an RBE greater than 1 after irradiation with neutrons, for the twotarget component would be suppressed after $\gamma$ irradiation, while it would respond preferentially to heavy ions.

These authors argue two ways, once that dose and RBE are meaningless, and a second time that the maximum in RBE at $z^{2} / \beta^{2}=2000$ supports the validity of their hypothesis that the mean free path, $\lambda$, is a suitable dosimetric variable, for at this value of $z^{2} / \beta^{2}, \lambda=2 \mathrm{~nm}$, related to the separation of the DNA strands in cells. To me this seems rather far-fetched, but if the authors can demonstrate how $\lambda$ predicts cross-sections for the interaction of heavy ions with cells, with viruses, with enzymes, with bacteria, and how it predicts thindown, I promise to reconsider. But not before the demonstration has taken place.

I must agree with the authors that RBE is a peculiar concept. All the more so when dose is obviously a peculiar concept. I refer in particular to measurements of RBE for very heavy ions at low dose where perhaps 0.1 or fewer of cells are traversed by a heavy ion (5). Clearly this is an aberration of the dose concept and leads to questionable values of $R B E$.

I do not think that criticism of dose or LET, or RBE or quality factor requires that the critic have in his pocket a practical recommendation for their replacement. It may be that no simplistic logical replacement is possible. When dose-response relationships are curvilinear, and are not "dose modifying," when the concept of a universal initial linear slope is not supported by experiment, this house of 
cards collapses. And carries with it that scientific aberration called the sievert.

Received: May 24, 1994

\section{REFERENCES}

1. R. Katz, Dose. Radiat. Res. 137, 410-413 (1994).

2. R. Katz and M. P. R. Waligorski, On the linear extrapolation to low doses. Radiat. Prot. Dosim. 52, 197-199 (1994).
3. K. G. Hofer, N. Van Loon, M. H. Schneiderman and G. V. Dalrymple, Targets for radiation induced cell death: Target replication during the cell cycle evaluated in cells exposed to X-rays or ${ }^{125} \mathrm{I}$ decays. Int. J. Radiat. Biol. 64, 205-216 (1993).

4. R. Katz, High LET constraints on low LET survival. Phys. Med. Biol. 23, 909-916 (1978).

5. E. L. Alpen, P. Powers-Risius, S. B. Curtis and R. DeGuzman, Tumorigenic potential of high-Z, high-LET charged-particle radiations. Radiat. Res. 136, 382-391 (1993). 